\title{
Article
}

http://dx.doi.org/10.11646/phytotaxa.173.3.1

\section{Massonia saniensis (Asparagaceae, Scilloideae), a new species from Lesotho, southern Africa}

\author{
WOLFGANGWETSCHNIG ${ }^{1 *}$,MARIOMARTÍNEZ-AZORÍN ${ }^{1,2}$, MICHAELPINTER $^{1}$, ANDREASBRUDERMANN $^{1}$, \\ GERFRIED DEUTSCH ${ }^{1}$, MANUEL B. CRESPO ${ }^{2}$, ANTHONY P. DOLD ${ }^{3} \&$ MARTIN PFOSSER $^{4}$ \\ ${ }^{1}$ Institute of Plant Sciences, NAWI Graz, Karl-Franzens-University Graz, Holteigasse 6, A-8010, Graz, Austria; \\ e-Mail:wolfgang.wetschnig@uni-graz.at \\ ${ }^{2}$ CIBIO (Instituto Universitario de la Biodiversidad), Universidad de Alicante, P. O. Box 99, E-03080 Alicante, Spain. \\ ${ }^{3}$ Selmar Schonland Herbarium, Department of Botany, Rhodes University, Grahamstown 6140, South Africa. \\ ${ }^{4}$ Biocenter Linz, J.-W.-Klein-Str. 73, A-4040 Linz, Austria. \\ *author for correspondence
}

Dedicated to Prof. Dr. Irmtraud Thaler on the occasion of her $90^{\text {th }}$ birthday.

\begin{abstract}
As part of a taxonomic revision of the genus Massonia, a new species, M. saniensis is here described from Lesotho (southern Africa). This species is at first sight similar to both $M$. wittebergensis and M. jasminiflora, but it differs in vegetative, floral, and molecular characters as well as by its distribution. A complete morphological description of the new species and data on biology, habitat, and distribution are presented.
\end{abstract}

Key words: Flora of Southern Africa, Hyacinthaceae, Massonieae, Taxonomy

\section{Introduction}

Hyacinthaceae sensu APG (2003) comprises ca. 1000 species of bulbous plants distributed through Africa and Europe extending to Asia, with only Oziroë Rafinesque (1837: 53) occurring in South America (Speta 1998a, b, APG 2003). Within this family, four monophyletic clades were accepted as the subfamilies Hyacinthoideae, Ornithogaloideae, Oziroëoideae and Urgineoideae (Speta 1998b, Pfosser \& Speta 1999, Manning et al. 2004, Martínez-Azorín et al. 2011). Alternatively, Hyacinthaceae is treated as part of Asparagaceae subfamily Scilloideae, and consequently the former subfamilies are reduced to the tribes Hyacintheae, Ornithogaleae, Oziroëeae and Urgineeae (APG 2009, Chase et al. 2009). We favour using Hyacinthaceae at the family rank, based on morphological and evolutionary grounds.

Three tribes-Massonieae, Pseudoprospereae and Hyacintheae-are accepted in subfamily Hyacinthoideae. Massonieae and Pseudoprospereae are distributed throughout sub-Saharan Africa, the Arabian Peninsula to India, while Hyacintheae occur in Eurasia and northern Africa (Speta 1998a, b, Wetschnig et al. 2002, Pfosser et al. 2003, Manning et al. 2004). The generic circumscription within the tribe Massonieae has shown important changes in the last decades. Two new genera-Namophila Müller-Doblies \& Müller-Doblies (1997: 77) and Spetaea Wetschnig \& Pfosser (2003: 87) — were recently described and some other genera were lumped into broader generic concepts, e.g. Brachyscypha Baker (1870: 393), Polyxena Kunth (1843: 294), and Periboea Kunth (1843: 292) into Lachenalia J.Jacquin ex Murray (1784: 314) (Manning et al. 2004); Drimiopsis Lindley \& Paxton (1851-1852: 73) and Resnova Van der Merwe (1946: 46) into Ledebouria Roth (1821: 194) (Manning et al. 2004); Androsiphon Schlechter (1924: 147), Amphisiphon Barker (1936: 19) and Neobakeria Schlechter (1924: 149) into Daubenya Lindley (1835: t. 1813) (Manning \& Van der Merwe 2002); and Whiteheadia Harvey (1868: 396) into Massonia Houttuyn (1780: 424) (Manning et al. 2004, 2011). The latter steps, leading to very broadly-conceived taxonomic units, were mainly based on preliminary and incomplete phylogenetic studies. Therefore it appears necessary to evaluate those proposals on the basis of more detailed phylogenies covering most of the species involved in each genus combined with a profound analysis of the morphological characters involved in those groups. Nevertheless, the taxonomy and systematics in the subfamily is far from being well understood, and the taxonomy within the Massonieae still remains poorly resolved. 


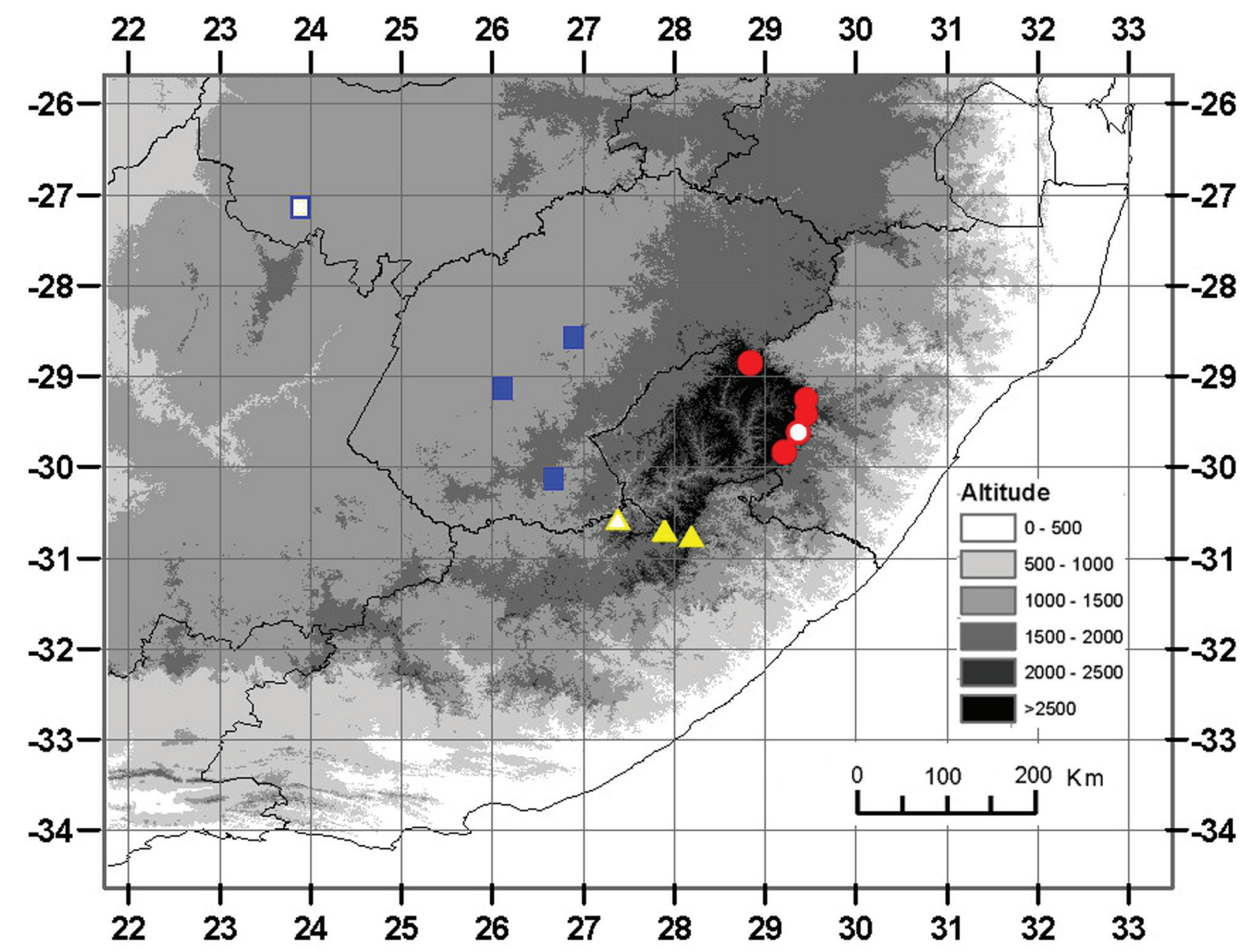

FIGURE 10. Known distribution of Massonia saniensis Wetschnig, Mart.-Azorín \& M.Pinter (red circles), Massonia wittebergensis U.Müll.-Doblies \& D.Müll.-Doblies (yellow triangles) and selected localities of Massonia jasminiflora Burch. ex Baker (blue squares). Type localities are indicated by symbols with white centres.

\section{References}

Angiosperm Phylogeny Group (2003) An update of the Angiosperm Phylogeny Group Classification for the orders and families of flowering plants: APG II. Botanical Journal of the Linnean Society 141: 399-436.

http://dx.doi.org/10.1046/j.1095-8339.2003.t01-1-00158.x

Angiosperm Phylogeny Group (2009) An update of the Angiosperm Phylogeny Group Classification for the orders and families of flowering plants: APG III. Botanical Journal of the Linnean Society 161: 105-121.

http://dx.doi.org/10.1111/j.1095-8339.2009.00996.x

Baker, J.G. (1870) A revision of the genera and species of herbaceous capsular gamophyllous Liliaceae. Journal of the Linnean Society. Botany 11: 349-436.

http://dx.doi.org/10.1111/j.1095-8339.1870.tb00068.x

Baker, J.G. (1896) Massonia jasminiflora Burch. ex Baker. Curtis's Botanical Magazine 122: t. 7465.

Baker, J.G. (1897) Liliaceae. In: Thiselton-Dyer, W.T. (ed.) Flora Capensis 6. Reeve and Co., London, pp. $253-525$.

Barker, W.F. (1936) Amphisiphon, a new genus of Liliaceae. Journal of South African Botany 2: 19-23.

Chase, M.W., Reveal, J.L. \& Fay, M.F. (2009) A subfamilial classification for the expanded asparagalean families, Amaryllidaceae, Asparagaceae and Xanthorrhoeaceae. Botanical Journal of the Linnean Society 161: 132-136.

http://dx.doi.org/10.1111/j.1095-8339.2009.00999.x

Galpin, E.E. (1909) A contribution to the knowledge of the flora of the Drakensberg. Report of the South African Association for the 
Advancement of Science $6^{\text {th }}$ Meeting: 209-229.

Harvey, W.H. (1868) Liliaceae. In: Hooker, J.D. (ed.) The genera of South African plants, arranged according to the natural system $2^{\text {nd }}$ edition. J.C. Juta, Cape Town, pp. 391-403.

Hilliard, O.M. (1990) Flowers of the Natal Drakensberg. The lily, iris and orchid families and their allies. University of Natal Press, Pietermaritzburg, $85 \mathrm{pp}$.

Hilliard, O.M. \& Burtt, B.L. (1987) The botany of the Southern Natal Drakensberg. National Botanic Gardens, 253 pp.

Houttuyn, M. (1780) Natuurlijke Historie of uitvoerige Beschryving der Dieren, Planten en Mineraalen, volgens het Samenstel van der Heer Linnaeus II, 12, Amsterdam, 558 pp.

IPNI (2014) The International Plant Names Index. Published on the Internet http://www.ipni.org [accessed February 2014].

Jacquin, N.J. (1791) Collectanea ad Botanicam, Chemiam, et Historiam Naturalem, Spectantia, cum Figuris 4. Wappler, C.F., Vindobonae, $359 \mathrm{pp}$.

Jessop, J.P. (1976) Studies in the bulbous Liliaceae in South Africa 6. The taxonomy of Massonia and allied genera. Journal of South African Botany 42: 401-437.

Kunth, C.S. (1843) Enumeratio plantarum omnium hucusque cognitarum, secundum familias naturales disposita, adjectis characteribus, differentiis et synonymis 4. Cottae, J.G., Stuttgardiae et Tubingae, 752 pp.

http://dx.doi.org/10.5962/bhl.title.67381

Leistner, O.A. \& Morris, J.W. (1976) Southern African Place Names. Annals of the Cape Provincial Museum 12: 1-565.

Lindley, J. (1835) t.1813 Daubenya aurea. Edwards's Botanical Register 21: t. 1813.

Lindley, J. \& Paxton, J. (1851-1852) 343. Drimiopsis maculata, Paxton’s Flower Garden ii. London: 73, fig. 172.

McNeill, J., Barrie, F.R., Buck, W.R., Demoulin, V., Greuter, W., Hawksworth, D.L. Herendeen, P.S., Knapp, S., Marhold, K., Prado, J., Prud'homme van Reine, W.F., Smith, G.F., Wiersema, J.H. \& Turland, N.J. (eds.) (2012) International Code of Nomenclature for algae, fungi, and plants (Melbourne Code), Adopted by the Eighteenth International Botanical Congress Melbourne, Australia, July 2011. Regnum Vegetabile 154. Koeltz Scientific Books, Königstein, 208 pp.

Manning, J.C. \& Goldblatt, P. (2003) Hyacinthaceae. In: Germishuizen, G. \& Meyer, N.L. (eds.) Plants of Southern Africa: An annotated checklist. Strelitzia 14: 1054-1071. National Botanical, Institute, Pretoria.

Manning, J.C., Goldblatt, P. \& Fay, M.F. (2004) A revised generic synopsis of Hyacinthaceae in Sub-Saharan Africa, based on molecular evidence, including new combinations and the new tribe Pseudoprospereae. Edinburgh Journal of Botany 60: 533-568. http://dx.doi.org/10.1017/s0960428603000404

Manning, J.C., Goldblatt, P. \& Saunders, R. (2011) Massonia bifolia. Hyacinthaceae. Curtis's Botanical Magazine 28: t. 721. http://dx.doi.org/10.1111/j.1467-8748.2011.01759.x

Manning, J.C. \& Van der Merwe, A.M. (2002) Systematics of the genus Daubenya (Hyacinthaceae: Massonieae). Bothalia 32: $133-150$.

Martínez-Azorín, M., Crespo, M.B. \& Juan, A. (2007) Taxonomic revision of Ornithogalum subg. Cathissa (Salisb.) Baker (Hyacinthaceae). Anales del Jardín Botánico de Madrid 64: 7-25. http://dx.doi.org/10.3989/ajbm.2007.v64.i1.47

Martínez-Azorín, M., Crespo, M.B. \& Juan, A. (2009) Taxonomic revision of Ornithogalum subg. Beryllis (Hyacinthaceae) in the Iberian Peninsula and the Balearic Islands. Belgian Journal of Botany 142: 140-162.

Martínez-Azorín M., Crespo, M.B., Juan, A. \& Fay, M.F. (2011) Molecular phylogenetics of subfamily Ornithogaloideae (Hyacinthaceae) based on nuclear and plastid DNA regions, including a new taxonomic arrangement. Annals of Botany (London) 107: 1-37. http://dx.doi.org/10.1093/aob/mcq207

Martínez-Azorín, M., Pinter, M., Crespo, M.B., Pfosser, M. \& Wetschnig, W. (2013) Massonia mimetica (Hyacinthaceae, Hyacinthoideae), a new remarkable species from South Africa. Stapfia 99: 187-197.

Mucina, L. \& Rutherford, M.C. (eds.) (2006) The Vegetation of South Africa, Lesotho and Swaziland. Strelitzia 19. South African National Biodiversity Institute, Pretoria, $807 \mathrm{pp}$.

Müller-Doblies, U. \& Müller-Doblies, D. (1997) A partial revision of the tribe Massonieae (Hyacinthaceae). Feddes Repertorium 108: 49-96.

Müller-Doblies, U. \& Müller-Doblies, D. (2010) De Liliifloris Notulae 8. Two new Massonia species (Hyacinthaceae) from South Africa. Feddes Repertorium 121: 127-132.

http://dx.doi.org/10.1002/fedr.201000022

Murray, J.A. (1784) Linnaeus. Systema vegetabilium, ed. 14. Dieterich, J.C., Göttingen, pp. 987.

Pfosser, M. \& Speta, F. (1999) Phylogenetics of Hyacinthaceae based on plastid DNA sequences. Annals of the Missouri Botanical Garden 86: $852-875$.

http://dx.doi.org/10.2307/2666172

Pfosser, M., Wetschnig, W., Ungar, S. \& Prenner, G. (2003) Phylogenetic relationships among genera of Massonieae (Hyacinthaceae) inferred from plastid DNA and seed morphology. Journal of Plant Research 116: 115-132. 
Pfosser, M., Knirsch, W., Pinter, M., Ali, S.S., Dutta, S. \& Wetschnig, W. (2012) Phylogenetic relationships of Malagasy Hyacinthaceae. Plant Ecology and Evolution 145: 65-72.

Phillips, E.P. (1917) A contribution to the flora of the Leribe Plateau and environs: with a discussion on the relationships of the floras of Basutoland, the Kalahari, and the South-Eastern Regions. Annals of the South African Museum 16: 1-379.

Phillips, E.P. [fide Manning \& Goldblatt 2003] (1930) Plate 367. Massonia bowkeri. Flowering Plants of Southern Africa 10 : t. 367.

Pinter, M., Brudermann, A., Crespo, M.B., Deutsch, G., Martínez-Azorín, M., Müller-Doblies, U., Müller-Doblies, D., Pfosser, M. \& Wetschnig, W. (2013) Massonia citrina (Hyacinthaceae, Hyacinthoideae) - a new species from the Western Cape Province (South Africa). Phytotaxa 112: 50-56.

http://dx.doi.org/10.11646/phytotaxa.112.2.3

Rafinesque, C.S. (1837) Flora Telluriana 3. H. Probasco, Philadelphia, PA, pp. 100.

Roth, A.W. (1821) Novae plantarum species praesertim Indiae orientalis : Ex collectione doct. Benj. Heynii : cum descriptionibus et observationibus. Vogler, Halberstadt, $412 \mathrm{pp}$.

http://dx.doi.org/10.5962/bhl.title.10723

Salisbury, R.A. (1866) The genera of plants. J.V. Voorst, London, 143 pp.

Schlechter, R. (1924) Drei neue Gattungen der Liliaceen aus Südafrika. Notizblatt des Botanischen Gartens und Museums zu BerlinDahlem 9(82): 145-151.

http://dx.doi.org/10.2307/3994398

Species-2000 (2014) Annual Checklist. Available at http://www.sp2000.org/ (accessed January 2014)

Speta, F. (1998a) Hyacinthaceae. In: Kubitzki, K. (ed.), The families and genera of vascular plants 3. Springer, Berlin, pp. $261-285$.

Speta, F. (1998b) Systematische Analyse der Gattung Scilla L. s.l. (Hyacinthaceae). Phyton (Horn) 38: 1-141.

Summerfield, A. (2004) A Synopsis of the biosystematic study of the seven minor genera of the Hyacinthaceae. Bulbs Bulletin of the International Bulb Society 6: 24-36.

Thiers, B. (2014) Index Herbariorum: A global directory of public herbaria and associated staff. New York Botanical Garden's Virtual Herbarium. Available from: http://sweetgum.nybg.org/ih/ (continuously updated; accessed: January 2014).

Van der Merwe, A. (2002) A biosystematic study of the seven minor genera of the Hyacinthaceae. Ph.D. Thesis, University of Stellenbosch [unpublished].

Van der Merwe, F.Z. (1946) Aantekeninge vir die hersiening van die genus Scilla L. in Suid-Afrika. 'n Nuwe genus: Resnova. Tydskrif vir Wetenskap en Kuns, Nuwe reeks 6: 41-46.

Wetschnig, W. \& Pfosser, M. (2003) The Scilla plumbea puzzle - present status of the genus Scilla sensu lato in Southern Africa and description of Spetaea lachenaliiflora, a new genus and species of Massonieae (Hyacinthaceae). Taxon 52: 75-91. http://dx.doi.org/10.2307/3647303

Wetschnig, W., Brudermann, A., Knirsch, W., Pinter, M. \& Pfosser, M. (2012) Massonia pustulata Jacq. 1791 and M. longipes Baker 1897 (Hyacinthaceae), two frequently misunderstood species_or how M. pustulata became depressed. Stapfia 97: 210-221. 